\title{
8
}
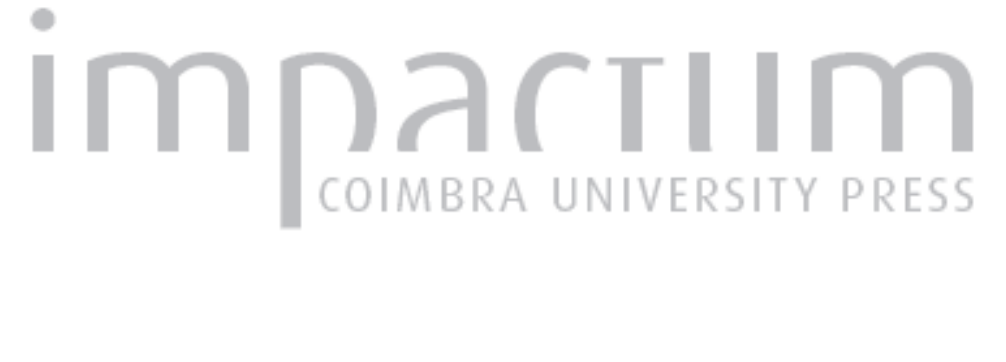

\section{Speaking in tongues: the return of typological studies}

\author{
Autor(es): $\quad$ Lopes, Diogo Seixas
}

Publicado por: Editorial do Departamento de Arquitetura

URL persistente:

URI:http://hdl.handle.net/10316.2/37280

DOI:

DOI:http://dx.doi.org/10.14195/1647-8681_4_25

Accessed : $\quad$ 26-Apr-2023 05:34:57

A navegação consulta e descarregamento dos títulos inseridos nas Bibliotecas Digitais UC Digitalis, UC Pombalina e UC Impactum, pressupõem a aceitação plena e sem reservas dos Termos e Condições de Uso destas Bibliotecas Digitais, disponíveis em https://digitalis.uc.pt/pt-pt/termos.

Conforme exposto nos referidos Termos e Condições de Uso, o descarregamento de títulos de acesso restrito requer uma licença válida de autorização devendo o utilizador aceder ao(s) documento(s) a partir de um endereço de IP da instituição detentora da supramencionada licença.

Ao utilizador é apenas permitido o descarregamento para uso pessoal, pelo que o emprego do(s) título(s) descarregado(s) para outro fim, designadamente comercial, carece de autorização do respetivo autor ou editor da obra.

Na medida em que todas as obras da UC Digitalis se encontram protegidas pelo Código do Direito de Autor e Direitos Conexos e demais legislação aplicável, toda a cópia, parcial ou total, deste documento, nos casos em que é legalmente admitida, deverá conter ou fazer-se acompanhar por este aviso.

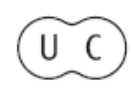




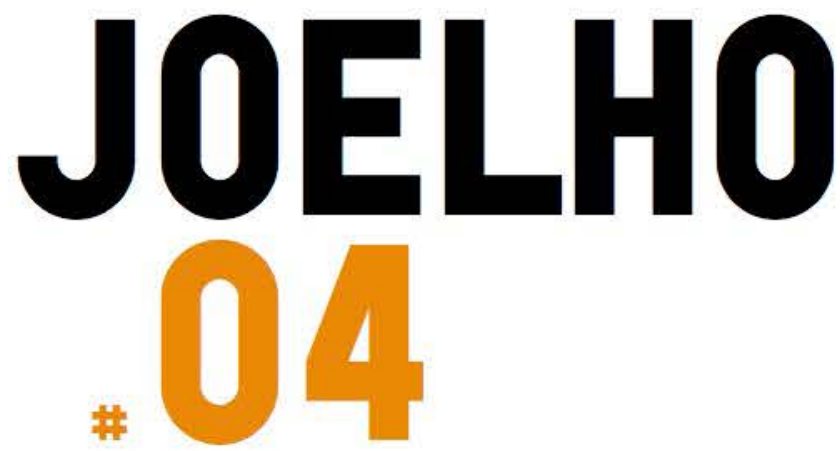

\section{ENSINAR PELO PROJETO \\ TEACHING THROUGH DESIGN}

\section{Coordenaçẫo:}

Paulo Providência

Gonçalo Canto Moniz

Alexandre Alves Costa Juan Domingo Santos Florian Beigel Philip Christou Elizabeth Hatz David Leatherbarrow Andrew Clancy Colm Moore Michael McGarry Willemijn Wilms Floet

Exposição TAPE 20Ir-12 


\section{Diogo Seixas Lopes Spealing in in tongues: the return of typological stúdies}

Speaking in tongues is a common expression for the word glossolalia, the usage of which is probably restricted to circles of the academia. Both terms relate to the idea of a sacred language, voiced by religious believers during meditation. Such language, seemingly impossible to understand, is made of broken syllables and vowels recited over and over. Due to their repetition, these particles of communication were the means to obtain a higher level of knowledge. The following presentation addresses the topic of teaching through design, and its need for synthesis, under a similar stance. It argues architecture must firstly be learned through the comprehension of its fundamentals. Type, a basic scheme of spatial organization, has been presented as such at different moments of the history of this disciplinary field. Its education - currently facing the pressure of cultural commodification, bureaucratic overkill, and budget cuts - should consider a return to typological studies. They can provide a solution, among others, to come back to the syllables and vowels of architecture.

\section{ๆ}

There is a tendency, specifically in Portugal, to emphasize the subjective aspects of architectural design. This trend is affiliated to the Beaux Arts and its teachings, based upon pictorial traditions and motifs. It is also indebted to a heroic idea of expression, wherein drawing traces a course of thought and action. However, as a path to personal discovery, drawing runs the risk of becoming an idiosyncratic quest for the Holy Grail. On the contrary, this overview calls attention to a positivist stance professed since the Enlightenment. From the eighteenth century onwards, there was an effort to bring rationale to modes of cognition making public criteria for the classification of knowledge. The editorial venture of the Encyclopédie Méthodique, initially promoted by Denis Diderot and Jean d'Alembert, gave an emblematic example of this effort. Among its endless roster of subjects, Antoine Quatremère de Quincy (1825, p.544) provided a definition for type:

The word 'type' presents less the image of a thing to copy or imitate completely than the idea of an element which ought itself to serve as a rule for the model. Thus, one should not say (or at least one with be wrong to say) that a statue, or the composition of a finished and rendered picture, has served as the type for the copy that one made. But when a fragment, a sketch, the thought of a master, a more or less vague description has given birth to a work of art in the imagination of an artist, one will say that the type has been furnished for him by such and such an idea, motif, or intention. The model, as understood in the practical execution of the art, is an object that should be repeated as it is; the type, on the contrary, is an object after which each [artist] can conceive works of art that may have no resemblance. All is precise and given in the model; all is more or less vague in the type. ${ }^{1}$

These principles apply to the activity of Jean-Nicolas-Louis Durand as a professor at the Polytechnic School in Paris, during that period. He taught architecture at this military institution, established as such in 1795, with the purpose of forming higher ranks of professionals to assist the construction of public works. 
Industrialization and demographic rise had sparked an escalating demand for technical expertise. Durand devised his pedagogic method based on this awareness, driven by the imperatives of convenience and economy. Faced with an increasing number of students, he declared inadequate the prevailing curricula of stylistic imitation that derived from classical treatises. In turn, he published his own supplements: Précis des leçons d'architecture (also known as "le petit Durand") and Recueil et parallèle des édifices (also known as "le grand Durand"). For the latter, he produced drawings of building types at the same scale arranged according to function and epoch. According to him, information for the students was captioned in this large handbook in detriment of the study of multiple bibliographic sources:

In this state of things, I thought if these three hundred volumes just mentioned were disposed of, the single objects that are of essential knowledge could be assembled into a single volume at a price equal to an ordinary architectural book. And thus offer to artists an affordable and general overview of architecture that they could survey in a short amount of time, examine without complication, and study with profit. Specially, if I classified the buildings and monuments by categories, grouped them according to their degree of analogy, and presented them at the same scale. And that is what I set out to do. ${ }^{2}$

(Durand, 1801)

The process of design taught by Jean-Nicolas-Louis Durand relied on these materials. Its focus was a procedure of architectural composition based upon elementary units and their assemblage, a "software of reproduction" avant la lettre. As Anthony Vidler described, "these elements - walls, columns, openings - were to be combined to form intermediate units - porches, stairs, halls and so on - and these again built into complete ensembles, which in turn formed towns." (Vidler, 1977, p.105) Bound by a strict sense of discipline, this system of design synthesis was nevertheless rooted by the sense of typology. Related to the institutional brief and social function of the project but, also, to its primary repertoire of samples. These were collated onto an album, of architectural specimens, that still fosters the imagination. It is an atlas of building types crisscrossing knowledge, by means of their designs and plans. In this sense, it brings to mind a commentary made by the writer Alain Robbe-Grillet (1989, p.165) about the novels of Franz Kafka: "The hallucinatory effect derives from the extraordinary clarity and not from mystery or mist. Nothing is more fantastic ultimately than precision."

\section{ๆ}

The advent of modern architecture pushed this program one step further, into the domains of abstraction. Refuting heritage from the past, viewed as unnecessary ballast and an obstacle to progress, design aspired to conquer the brave new world of mass production and socioeconomic revolution. Its rhetoric of innovation had famous proclamations, like the dictum of Le Corbusier (1924, p.16) about the house as "a machine for living." On the level of pedagogy, it is significant how a pioneering school such as the Bauhaus discarded history from its curricula. Proficiency of building types became a souvenir of institutions from the ancien régime and, thus, of no use for the avant-garde. Teaching strived to establish universal standards presiding over reality, among which the ergonomics of an Existenzminimum. This ambition eventually reverted to ideological indifference, imposing formulaic and functionalist dogmas regardless of specific conditions.

The return of typological studies during the second half of the last century was a response to this status quo. In 1962, Giulio Carlo Argan (1962, p.96-101) published an influential essay about the subject. Rather than a spatial schema, he described type as a cultural instance. In other words, "when a 'type' is determined in the practice or theory of architecture, it already has an existence as an answer to a complex of ideological, religious or practical demands which arise in a given historical condition of whatever culture." (Argan, 1962, p.565) It was thus necessary to transcend classifications strictly based upon contingency, in order to comprise other aspects such as formal identity. For instance, the layout that derived from the circular shrine was frequently readjusted to other purposes. Thus, Argan concluded, "the typological and the inventive aspect of a creative process are continuous and interlaced - the inventive aspect being merely that of dealing with the demands of the actual historical situation by criticizing and overcoming past solutions deposited and synthesized schematically in the 'type'" (Argan, 1962, p.96-101)

These considerations were a precedent to the research conducted by Aldo Rossi in the 1960s. During that decade, he taught at the Architectural Institute of Venice and the Polytechnic Institute of Milan producing typological surveys with students. Among other tasks, they charted a timeline of constructions across the ages. The proceedings of this activity provided primary sources for his first book, L'architettura della città. ${ }^{3}$ Published in 1966, it conflated substantial data from this academic background. Acknowledged as an instant classic due to its editorial success, the impact of this work over architectural theory and practice prevailed until today. It affected legions of followers, as well as fierce rivals. Devised as a contemporary treatise, L'architettura della città exerted appeal due to the simplicity of its starting point. In essence, the city was a product of architecture. Type had a great part in this claim, ensuring scientific autonomy for its field as a specific area of knowledge:

Thus typology presents itself as the study of types of elements that cannot be further reduced, elements of a city as well as of an architecture. The question of monocentric cities or of buildings that are not centralized, for example, is specifically typological; no type can be identified with only one form, even if all architectural forms are reducible to types. The process of reduction is a necessary, logical operation, and it is impossible to talk about problems of form without this presupposition. In this sense all architectural theories are also theories of typology, and in actual design it is difficult to distinguish the two moments.

(Rossi, 1982, p.41) 
The full scope of these ideas would take shape in the projects of Aldo Rossi, ensuring a different kind of reception due to their formal power. They were architectural demonstrations of a theoretical program, validating each other. Used as an archeological relic, or a collectible item, type could be redeployed into new configurations and circumstances as a structure for collective memory. "Ultimately, we can say that type is the very idea of architecture, that which is closest to its essence." (Rossi, 1982, p.41)

Time has shown how the propositions of Aldo Rossi created a dead end of their own, wherein obsessive morphological analysis blocked spontaneous synthesis through design. The problem of choice and invention persisted, despite revisions of formal templates. Aldo van Eyck (1985, p.112), "the other Aldo," contested this creed when he wrote "cowards always turn to fixed types and ready-mades, or play foul visà-vis history, whilst real archetypes scare them - the 'typophiles' - out of their wits." Replying to an inquiry about typology, he illustrated this altercation with the plan of a tribal farm in the Cameroon and judged that "the whole typological hocus pocus has classified nothing of validity, revaluated nothing and effectuated no new useful types, which could survive multiplication." (Eyck, 1985, p.112) In retrospect, it is true that the theoretical commandments of Rossi induced pedagogic stasis. Yet, the polemic of van Eyck also seems a liberal naiveté these days. In fact, diversity was conveniently converted into currency for the countless niche markets of worldwide urbanization.

Recently, several teaching institutions have rehearsed a call to order regarding these questions. At the Swiss Federal Institute of Technology in Zurich (ETH), such is the case of the course units of Christ Gantenbein. Since 2010, this architectural practice from Basel began a series of design studios based upon the notion of typology transfers. There is a sense of lineage in this program since Emanuel Christ and Christoph Gantenbein were taught or collaborated with Jacques Herzog, Pierre de Meuron, Roger Diener, and Marcel Meili. In turn, these prominent figures from the staff of the ETH found an early influence there during the 1970s under the guest professorships of Aldo Rossi. His legacy of the architecture of the city comes back, once again, as an updated modus operandi:

Our typology is an inventory of the metropolitan, largely anonymous building production of the $2 \mathrm{O}^{\text {th }}$ century, a survey, so to speak, of today's urban architecture. What looks like an alternative architectural history of the $2 \mathrm{O}^{\text {th }}$ century, a history of architecture without architects, is our trove of urban projects. They're all solutions and typological strategies which demonstrate that urban density can be realized under real economic pressure in such a way that a specific form with great architectural quality can be obtained. Nevertheless, due to their typological rationality, the architectural objects often appear more imaginative than many a so-called free design. We want to learn from this. Hence the idea of a typology transfer: why can't a gallery building like those found in the hills of Hong Kong, an expressive setback office building from Manhattan, or a fully-built block comprising highly different building types also exist in Zurich?"

(Christ and Gantenbein, 2012, p.12)

The experiment continued onto other destinations, such as Rome and Buenos Aires. Each semester is dedicated to one of them, as the source for typology transfers. Teachers, assistants, and students visit the chosen city to carry on preliminary fieldwork and location scouting. After reconnaissance, they record their findings. Somewhere between a guidebook and a catalogue, this record contains data - plans, axonometric perspectives, and historic notes - about local building types. Students use them as blueprints, imported onto a specific site in Zurich. The process resembles fusion cooking, resorting to exotic ingredients to spice up a current dish. On this particular case, each recipe must create higher levels of urban density and unique modes of spatial conglomeration for the purpose of housing. Throughout the semesters, students have sprinkled the city with a kaleidoscope of these crossbred specimens. They originated from indigenous species with names such as "pencil towers," "palazzinas," "setbacks," and "chorizo houses." Despite its strictness, this method gives rise to a variety of urban projects. While the procedure is almost martial, enforcing a clear set of rules, it also ensures good average results for the whole of a workgroup.

With typical Swiss efficiency, Christ Gantenbein created a formula for success. Significantly, it was branded and marketed onto other franchises. Early this year, an omnibus volume was published documenting the academic results of the first four semesters. In addition, earlier this month, an application for the IPhone was launched with contents from the course units. (Christ and Gantenbein, 2013) (fig.l) Resorting to the so-called augmented reality of the digital interface, the application is a navigator proposing an altogether different kind of Grand Tour. Thus, typology is all around.

\section{१}

From the standpoint of Portugal, the resources of the higher tier of Central European and Anglo-Saxon architectural schools sound like science fiction. This handicap poses a problem of poor academic performance on the international level and, more importantly, lack of cultural presence on a broader context. Without this, local skills and references are bound to fall into oblivion. While a return to typological studies is but a fraction of a more complex equation, it nevertheless prefigures the shape of things to come. That is, the urgency of systematic and clear curricula ranging from technical to artistic tasks. It is necessary to start from scratch, in order to secure continuity with the past. Between resistance and scarceness, Portugal has a long tradition of "plain architecture." There, we can find the very idea of this profession, closest to its essence. Typology is one of the means to learn this since it is, indeed, all around. 
T1

Pencil Tower
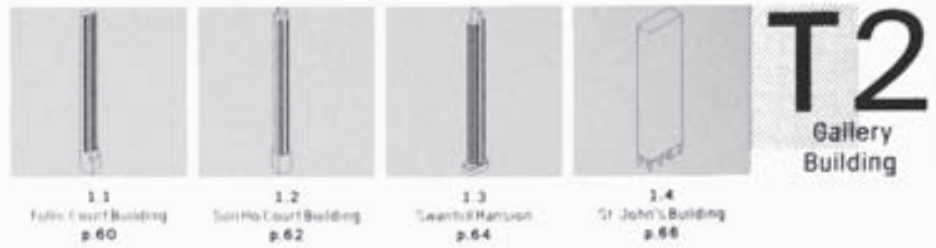

Building

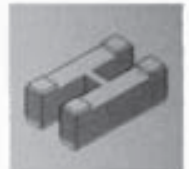

2.1
Menko
$=70$
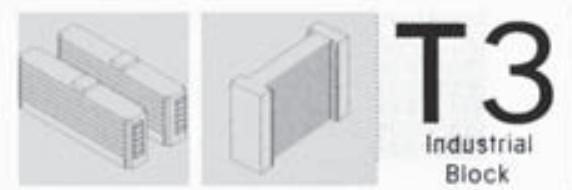

Industrial

Block

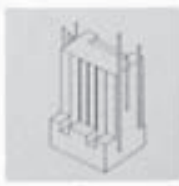

31
nogterinoushai

Buleng

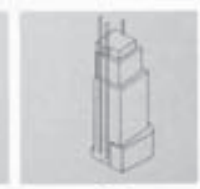

3.2

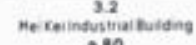

$\rightarrow \infty 0$

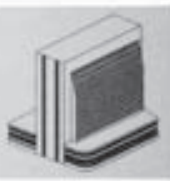

3.3

Heu fengindustria!

Buidne

12
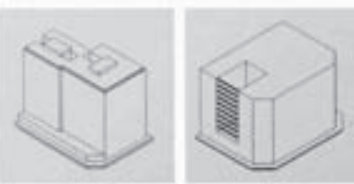

3.7

3.6

of as
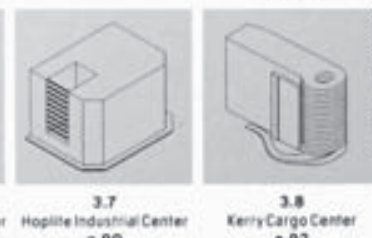

$\underset{0.92}{3.0}$

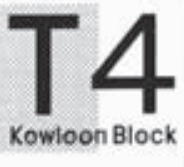

Kowloon Block

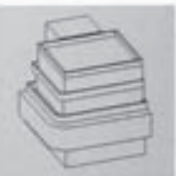

41

Mido Cate
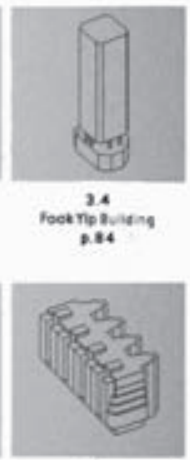

Numcheovg 4 ment

o. 98
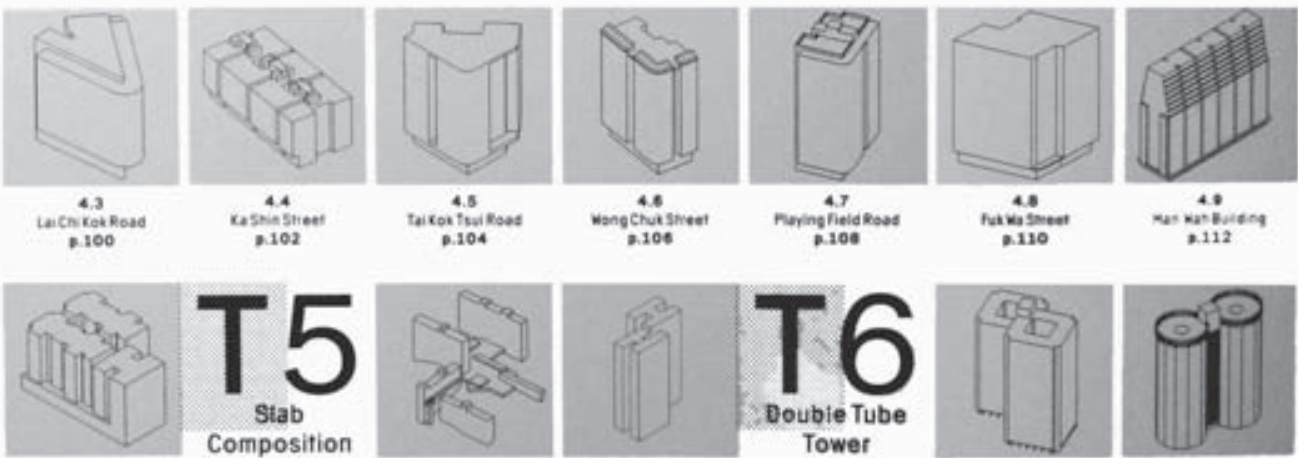

Stab

Composition

4.10
aking Manvion

D.114
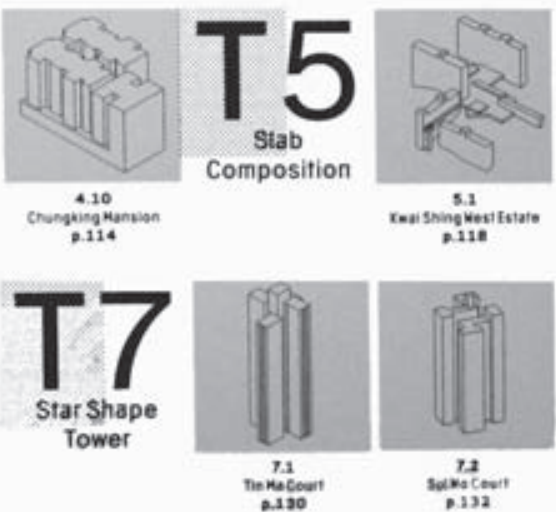

5.3

5.2 D.11e

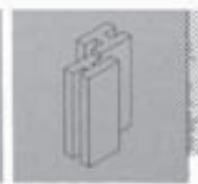

5.2
vaveifstate

raveifstate

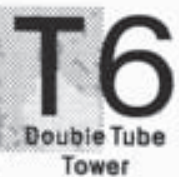

Tower

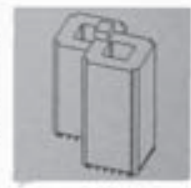

61

oikentisare

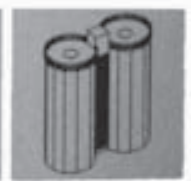

42

0.120
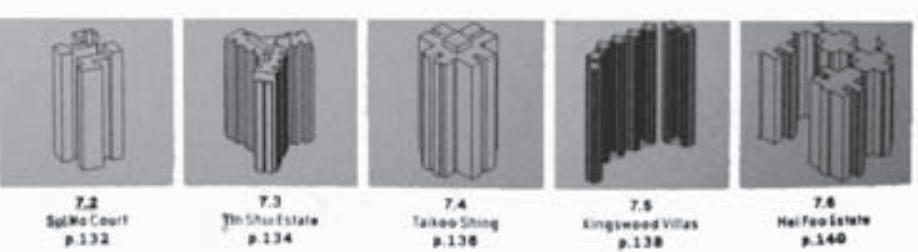

1. Christ, E., Gantenbein, C. (2013). iPhone Typology Apps,

https://itunes.apple.com/ch/app/hk-typology/id555344974? $\mathrm{mt}=8$

(last access on March 17, 2013). 
$1 \rightarrow$ Quatremère de Quincy, "Type," in Encyclopédie Méthodique, Architecture, vol. 3, (Paris: Agasse, 1825), p. 544 / "Type," tr. Anthony Vidler, Oppositions, no. 8 (Spring 1977): p. 148. The original definition in French is: "Le mot type présente moins l'image d'une chose à copier ou à imiter complètement, que l'idée d'un élément qui doit lui-même servir de règle au modèle. Ainsi on ne dira point (ou du moins aurait-on tort de le dire) qu'une statue, qu'une composition d'un tableau terminé et rendu, a servi de type à la copie qu'on en a faite. Mais qu'un fragment, qu'une esquisse, que la pensée d'un maître, qu'une description plus ou moins vague, aient donné naissance, dans l'imagination d'un artiste, à un ouvrage, on dira que le type lui en a été fourni dans telle on telle idée, par tel ou tel motif, telle ou telle intention. Le modèle, entendu dans l'exécution pratique de l'art, est un objet qu'on doit répéter tel qu'il est. Le type est, au contraire, un objet d'après lequel chacun peut concevoir des ouvrages qui ne se ressembleraient pas entr'eux. Tout est précis et donné dans le modèle, tout est plus ou moins vague dans le type."

$2 \rightarrow$ Jean-Nicolas-Louis Durand, Recueil et parallèle des édifices de tout genre, anciens et modernes (Paris: Chez l'Auteur, 1801), np. "Dans cet état de choses, j'ai pensé que si détachant des trois cents volumes dont je viens de parler, les seuls objets qui sont essentiels à connaître, je les rassemblais dans un seul volume d'un prix tout au plus égal à celui d'un ouvrage ordinaire d'architecture; ce serait offrir aux artistes un tableau général et peu coûteux de l'architecture, un tableau qu'ils pourraient parcourir en peu de temps, examiner sans peine, étudier avec fruit; surtout, si je classais les édifices et les monuments par genres; si je les rapprochais selon leur degré d'analogie; si je les assujetissois en outre à une même èchelle : et c'est que j'ai entrepris de faire."

$3 \rightarrow$ Namely, the transcripts of the course "Caratteri distributivi degli edifici," taught at Istituto Universitario di Architettura di Venezia. See Rossi, A. et al. (1964), Aspetti e problemi della tipologia edilizia. Venice; Rossi, A. et al. (1965), La formazione del concetto di tipologia edilizia. Venice; Rossi, A. et al. (1966), Rapporti tra morfologia urbana e tipologia edilizia. Venice. For a detailed analysis of the context of the book see Roveri, E. V. (2010). Aldo Rossi e L'architettura della città. Genesi e fortuna di un testo. Turin: Umberto Allemandi.

\section{Bibliographical References}

Argan, G., C., (1962), Sul concetto di tipologia architettonica, in Karl Oettinger and Mohammed Rassem (ed.) Festschrift für Hans Sedlmayr, Munich: C.H. Beck, pp.96-101.

Argan, G., C., (1963), On the Typology of Architecture, Architectural Design 33, 12, pp.564-565. trans. Joseph Rykwert.

Christ, E., Gantenbein, C. (2012). Typology - Hong Kong, Rome, New York, Buenos Aires. Zurich: Park Books, p.12.

Christ, E., Gantenbein, C. (2013). iPhone Typology Apps, https://itunes.apple.com/ch/app/hk-typology/ id555344974? $\mathrm{mt}=8$ (last access on March 17, 2013).

Eyck, A. van (1985), "Ten Opinions on the Type," Casabella 49, 509/510, p.112.
Durand, J-N-L (1801). Recueil et parallèle des édifices de tout genre, anciens et moderne. Paris: Chez l'Auteur.

Le Corbusier (1924), Vers une architecture. Paris: Crès.

Quincy, Q. de (1825). Type, in Encyclopédie Méthodique, Architecture, (3). Paris: Agasse, 544.

Quincy, Q. de (1977), Type, Oppositions, 8, p.148. Tr. Anthony Vidler.

Robbe-Grillet, A. (1989). For a New Novel: Essays on Fiction. Evanston, IL: Northwestern University Press, p.165. [1963], tr. Richard Howard.

Rossi, A. et al. (1964), Aspetti e problemi della tipologia edilizia. Venice.
Rossi, A. et al. (1965), La formazione del concetto ditipologia edilizia. Venice.

Rossi, A. et al. (1966), Rapporti tra morfologia urbana e tipologia edilizia. Venice.

Rossi, A., (1982). The Architecture of the City, Oppositions Books, Cambridge, MA: MIT Press, p.41. (1966). intro. Peter Eisenman, tr. Diane Ghirardo and Joan Ockman.

Roveri, E. V. (2010). Aldo Rossi e L'architettura della città. Genesi e fortuna di un testo. Turin: Umberto Allemandi.

Vidler, A. (1977). The Idea of Type: The Transformation of the Academic Ideal, 1750-1830, Oppositions, 8, p.105. 